\title{
Building GIS data \& sustainable master plan for Haddatha village
}

\author{
Soha Bdeir $^{1}$, Mohammad Abboud ${ }^{2}$ \\ ${ }^{l}$ Lebanese International University, Department of Surveying Engineering, Lebanon \\ ${ }^{2}$ School of Engineering Lebanese International University, Chair of Surveying Department, Lebanon
}

\begin{abstract}
Places are built and expand as society grows. Nowadays, it is essential to use a sustainable approach to the use of natural resources. Presently, the whole world must create a digital model, archive data, and build villages and cities using digital information. Accordingly, the objective of this project is to build geodatabase and create a master plan for Haddatha. Haddatha is a village on the border with southern Lebanon, which to this day suffers from a lack of proper urban planning. GIS and sustainable master plan were built for this village to identify information about roads, land plots, zoning, and planning.
\end{abstract}

\section{Introduction}

Urban planning can be defined as a technical and political process involved in the development and design of land use and the built environment, including air, water, and the infrastructure inside and outside of urban areas, such as transportation, communications, and distribution network. It is an art that creates the appropriate environment allowing the human communities to evolve, grow up, and achieve their aspirations.

A sustainable master plan is needed to reduce the destructive impact on our environment and the greenhouse effect through building materials and the use of sustainable development principles in construction development. The sustainable development as applied to architecture focuses on the construction and design of environmentally friendly buildings. Architectural engineering seeks to improve building management and residents' health by reducing energy consumption and environmental impact through the application of clean technologies. A building must be ecological which means that the building should rely on natural materials.

Lebanon is a state in the Middle East. It shares borders with Syria to the north and east for $376 \mathrm{~km}$ and Palestine to the south for $79 \mathrm{~km}$. It is bordered on the west by the Levantine Basin, the eastern part of the Mediterranean Sea, with $220 \mathrm{~km}$ of coastline.

In Lebanon, there were several construction booms. Oneboom took place after the civil war. The civil war lasted for 15 years until 1990, which led to the destruction of Lebanon. After the end of the war, the extensive damage to buildings and infrastructure became visible. The previous initiative to rebuild war-ravaged areas began with a 1991 law that gave municipalities the authority to create real estate developing companies to work in the destroyed areas. In this previous reconstruction period, the role of the Lebanese state was limited to the formation of these companies, identifying specific geographical areas for 
development, and often providing support to facilitate the construction of infrastructure. This boom covered all areas of Lebanon except for the occupied southern villages.

Another construction boom emerged in 2000 when the Israeli enemy withdrew from the southern villages. At that time, the construction movement appeared. This movement became more active after the July 2006 war, but acted indiscriminately.

In 2006, Israel destroyed public networks, power systems, and civilian homes...Also, Israel destroyed apartments, houses, electricity, water services, roads, bridges, factories, and ports. This war had great effects on Lebanon, especially in the south, where 20 villages, including Haddatha, witnessed extensive destruction. After the war, the government limited its activities to receiving financial assistance from Arab donors.The government was blamed for its weak role and incomplete post-war reconstruction efforts. Despite all these subsidies, the responsible authorities did no proper reconstruction. Until now, most villages and cities still suffer from a lack of necessary infrastructure.

We are trying to build GIS data for a particular village, and create a sustainable master plan for the reconstruction of public utilities and daily amenities, and modernization of the village, in a way to meet the needs for diversity and unity $[1,2,3]$.

\section{Bibliography}

The Master Plan is a comprehensive long-term plan to regulate the future use of land and infrastructure within the framework of local goals, objectives, and policies for community growth or redevelopment.

The sustainable Master Plan Study includes recommendations, analysis, and proposals for the economy, population, housing, community facilities, transport, and land use.

There is a relationship between the master plan and the zoning decree. The Zoning Act helps regulate land use. This law specifies the main use of land (agricultural, residential, industrial, or commercial land, investment factors allowed for construction ...).

Geography plays an important role in the choice of where cities are located, their role, the type of activities they perform, and their potential for future expansion. On this basis, cities are geographically disproportionately affected by key elements of urban development, such as topography, water resources, and economic activity.

Ancient civilizations emerged in many parts of the world, at various times over 3000 B.C., but the first and most important of them originated in specific geographical areas.

Water and air are the most important elements for the survival of living organisms. Most of the ancient civilizations originated on the banks of rivers.

Urbanization spread rapidly throughout the world, with the beginning of the agricultural and industrial revolution in the late eighteenth century. Since 1950, this idea has taken root in the developing world. By the beginning of the 20th century, $15 \%$ of the world's population lived in cities, and in 2007, in cities lived already $50 \%$ of the world's population $[4,5,6]$. 

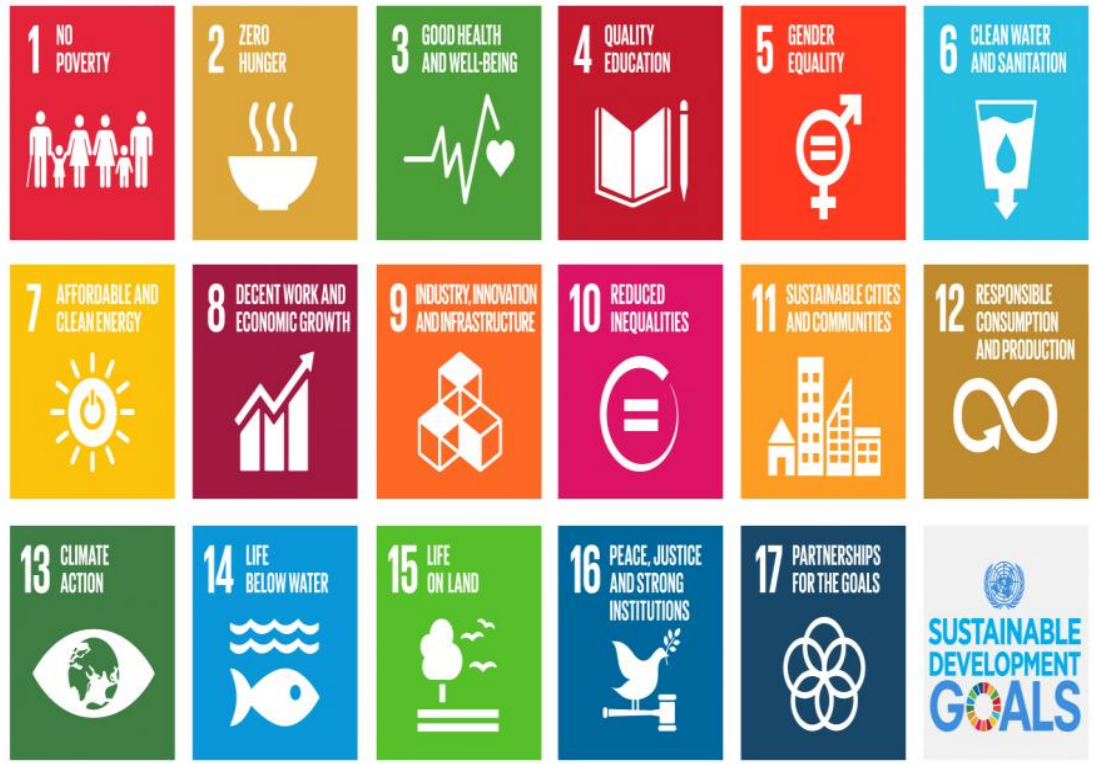

Fig. 1. Sustainable Development Goals - SDGs (United Nation).

On September 25, 2015, the 2030 Agenda was adopted by the United Nations General assembly; it is a set of 17 Sustainable Development Goals (a plan to achieve a better and more sustainable world so that the next generation and enjoy a good and equal way of life). The SDGs set great expectations for countries facing challenges such as health, education, poverty, women's empowerment and equality, growth, and environmental protection. The goals of sustainable development based on addressing issues closely related to Lebanon and its population, including those related to equality, economic growth, governance, and the environment, provide an opportunity to develop an ambitious and shared vision of Lebanon's Future. The SDGs will provide opportunities for the Lebanese to work together for a better and more equal future for themselves and for the next generations of Lebanese $[2,7,8]$ (As we can see in Figure 1).

Green buildings are resource-efficient throughout the building's life cycle, from construction to design, maintenance, operation, dismantling, and refurbishment. Green buildings reduce energy consumption by applying clean technologies through reliance on natural resources. The green building concept is applicable not only to new constructions, but also renovating old buildings so that they can obtain green building certification, so green buildings can be homes, schools, and high-rise buildings, big or small.

There are many goals that green buildings can achieve among the 17 goals. These include:

Goal\#3: According to the World Health Organization, respiratory and lung diseases associated with a poor quality of the indoor environment are among the most important causes of death. The way a building is designed can affect the well-being and health of its residents. Green building features, such as green spaces and better air quality, have been shown to positively impact health and well-being. Also, green buildings can help reduce 
emissions from buildings and thus improve air quality and reduce pollution, which will benefit the health of the population.

Goal\#7: Green buildings use renewable energy, the main advantage of which is the reduction of carbon dioxide emissions, which reduces their environmental impact and can be cheaper than using alternative fossil fuels.

Goal\#8: As the demand for green buildings grows, so does the workforce, as more jobs are available from construction and operations to renovation.

Goal\#9: Green buildings must be designed in a way that is adaptable to changing construction and ensures that they are resilient. This is not just about future buildings, but also infrastructures that must be sustainable and resilient to future risks.

Goal\#11: The built environment that contributes to the formation of societies must be sustainable to ensure a high quality of life for all. Green buildings are essential and are the foundations of societies and cities for their long-term sustainability (whether they are homes, schools, stores, offices, or green spaces).

A few examples of cities:

a) Lebanon:the UNDP ${ }^{(3)}$ implements Lebanon's sustainable development project using the 17 SDGs (as we can see in figure 2):

Goal\#3: Good Health and Well-Being: a world without diseases,physical and mental,achieved through high-quality health care systems, which cover and protect all people."

In Lebanon, significant progress has been made in increasing life expectancy and reducing killer diseases, such as respiratory and coronary heart disease, and improving access to quality health services. There is still worktobe done by every municipality to improve the health of the population and ensure affordable health care for all.

Goal\#7: Affordable and Clean Energy: "Ensuring affordable, reliable, and efficient energy while also increasing the use of renewable energy."

In Lebanon, up to $4.5 \%$ of electricity comes from hydropower and up to $95.5 \%$ from oil. In 2012, EDL achieved only $63 \%$ of the electricity demand in Lebanon. In $2012,53 \%$ of Lebanon's total greenhouse gas emissions were from the energy sector [2].

By moving away from diesel oil as the main fuel for energy to more sustainable forms of fuels, citizens could access more affordable energy while also improving the environment.

GOAL\#12: Responsible Consumption and Production: "Sustainable consumption and production involve the efficient management of natural resources and chemicals and the reduction of waste pollutant products."

In 2000, Lebanon implemented environmental legislation requiring industries to reduce pollution. We must change the way we use to produce and consume goods and resources for economic growth and sustainable development. Awareness of the benefits of sustainable consumption and production patterns helps transform the economy into a green economy and is a great support in reducing the negative impact on the environment. Therefore, it should encourage the cultivation of known crops that can improve financial performance, improve health and wellobeing, and eliminate market failures. The irrigation water from safe natural water resources must be provided. Recycling and waste management must be undertaken to eliminate toxic and contaminated waste to achieve the goals.

b) Masdar city, for instance, is a planned city project in Dhabi, in the United Arab Emirates. It was established in 2008 and covers an area of six square kilometers.

Masdar City relies on alternative and renewable energy sources, the most important of which is solar energy [3].

A master plan for the city was developed based on providing a livable, minimum polluted living. Land use in the city was classified as 30\% for housing, $24 \%$ for R\&D, and $19 \%$ for services and transportation. The infrastructure, including roads, metro, and light 
rail (LRT) lines, was built to connect Masdar to neighboring communities and the international airport. The city is designed to encourage a pedestrian culture, while shaded streets and patios provide an attractive pedestrian environment, protected from climatic fluctuations. The establishment of wind and solar farms in the surrounding areas and research fields and farms allowed the city community to become self-sufficient in the field of energy. As we can see in Figure 2, the project is divided into two sectors, connected to an elongated park .Each building must receive at least 3 grades of pearls, according to the Pearl Building Classification System. Low-carbon cement was used for building construction, and some green buildings were constructed to reduce energy and water consumption.

The source of the Wind Tower is the contemporary interpretation of the traditional Arabian Wind Tower. At a height of 45 meters, the tower captures wind from the top floor and directs it to the public square at its base for cooling. The sensors at the top of the steel structure open the doors in the direction of the prevailing wind to drop the wind to the lower part of the tower.

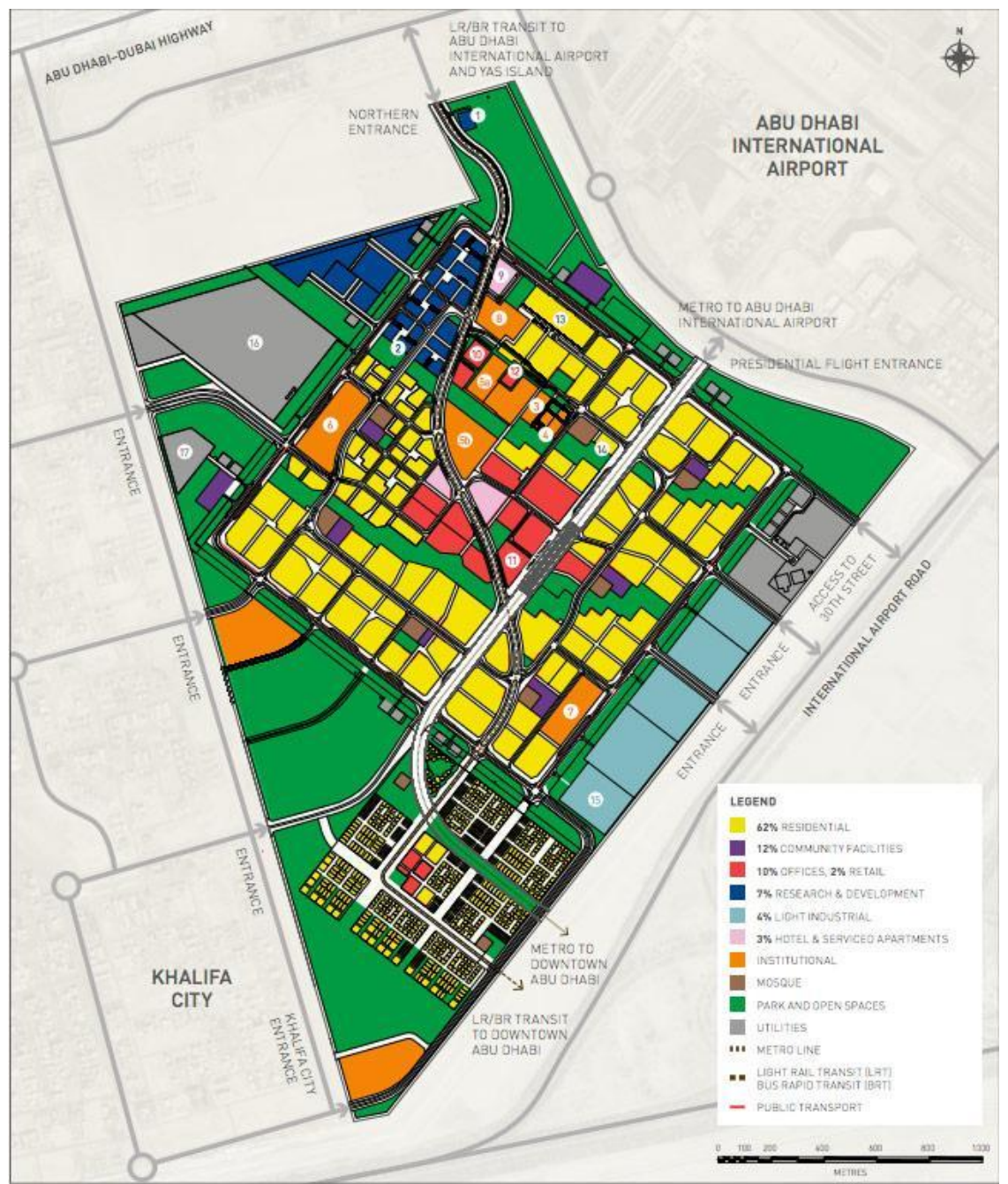

Fig. 2.Master Plan Map of MASDAR City 


\section{Methodology}

\subsection{Study area}

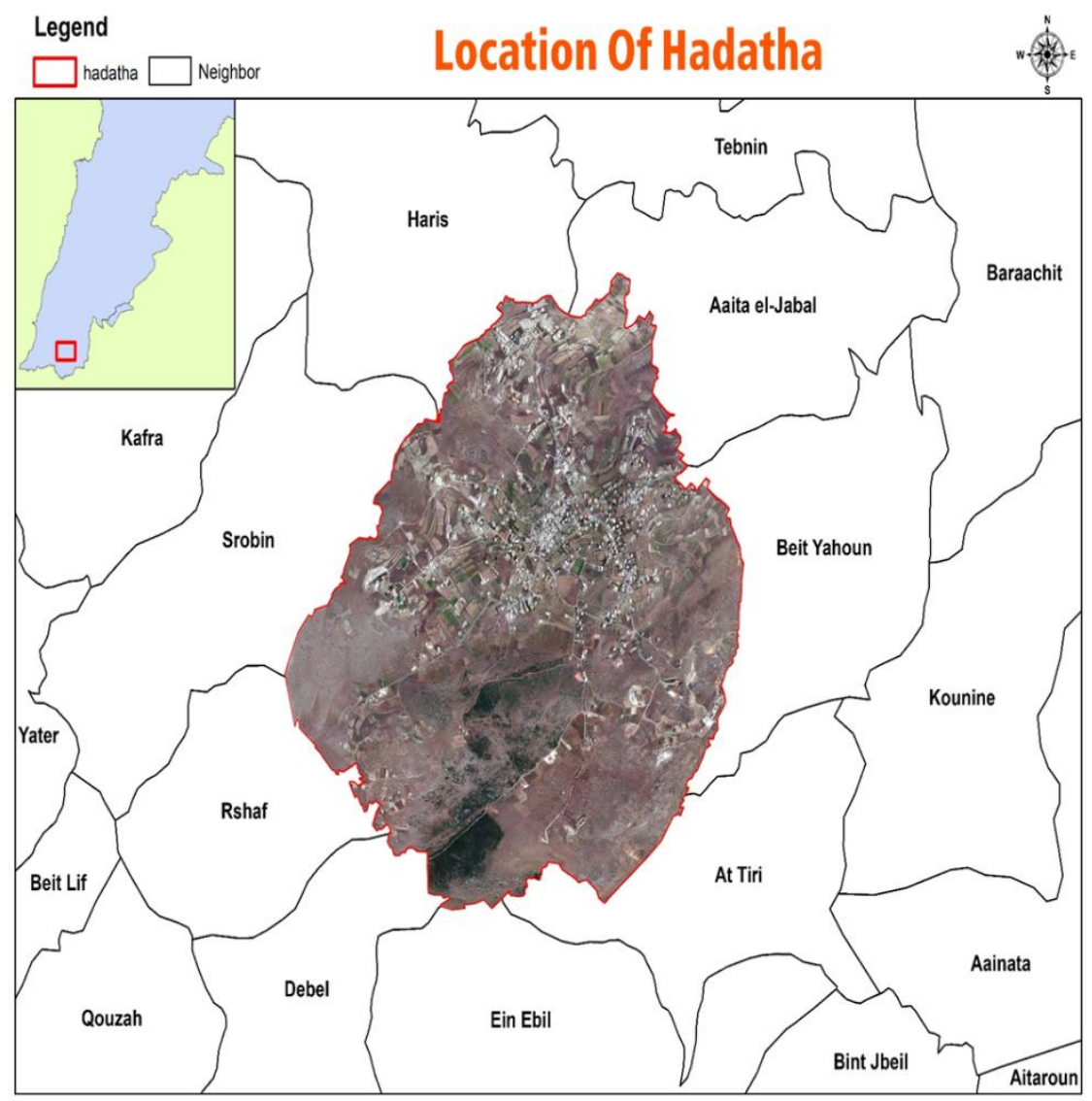

Fig. 3. Location of Haddatha.

The location of any country is analyzed first by studying regional and national geography: the sea, rivers, and mountains, and then it is juxtaposed with human resources and political, linguistic, and religious boundaries. Finally, it should take into consideration economic and transport data.

Haddatha is a village in the district of Bint Jbeil, the Nabatieh Governorate, located on a hill overlooking the sea and surrounded by hills on each side. Its area is about $9 \mathrm{~km}^{2}$.

It has a good economic development, including agricultural, commercial, and industrial progress. It became more active after 2000; the village recently went through a boom in reconstruction, which led to the construction of many shops and factories. The village has some ancient springs and ponds, which contributed to the prosperity of agricultural progress; tobacco cultivation comes first among crops and is the main source of livelihood for the residents, but there are many seasonal crops as well. Some agricultural roads have been built to make it easier for farmers and peasants to access their land plots.

In terms of infrastructure, there currently are nine power transformers in the city sufficient to provide electricity in Haditha. Most internal and external roads are paved, especially those connecting Haddatha to neighboring villages. Most of the secondary roads 
in the city are paved, wooded and lighted. However, most internal roads still lack infrastructure, paving, and afforestation. There is a football stadium, but it is old and needs renovation and redesign. Since 2010, the support walls have been built and expanded on public roads, especially those connecting the city to neighboring towns, with a width of 10 meters and above. Although the population has increased from year to year, the sewage networks are still absent. The village has a public garden, which is considered as a reserved area, and, unfortunately, this garden hasn't received any sufficient attention from the decision-makers, especially after the fire that took place in July 2019 and burnt a large number of trees $[9,10,11]$.

\subsection{Study area}

The methodology is a strategy that intends to give details about the four main sampling procedures, which is identifying, data collection, map preparation, and field visit.

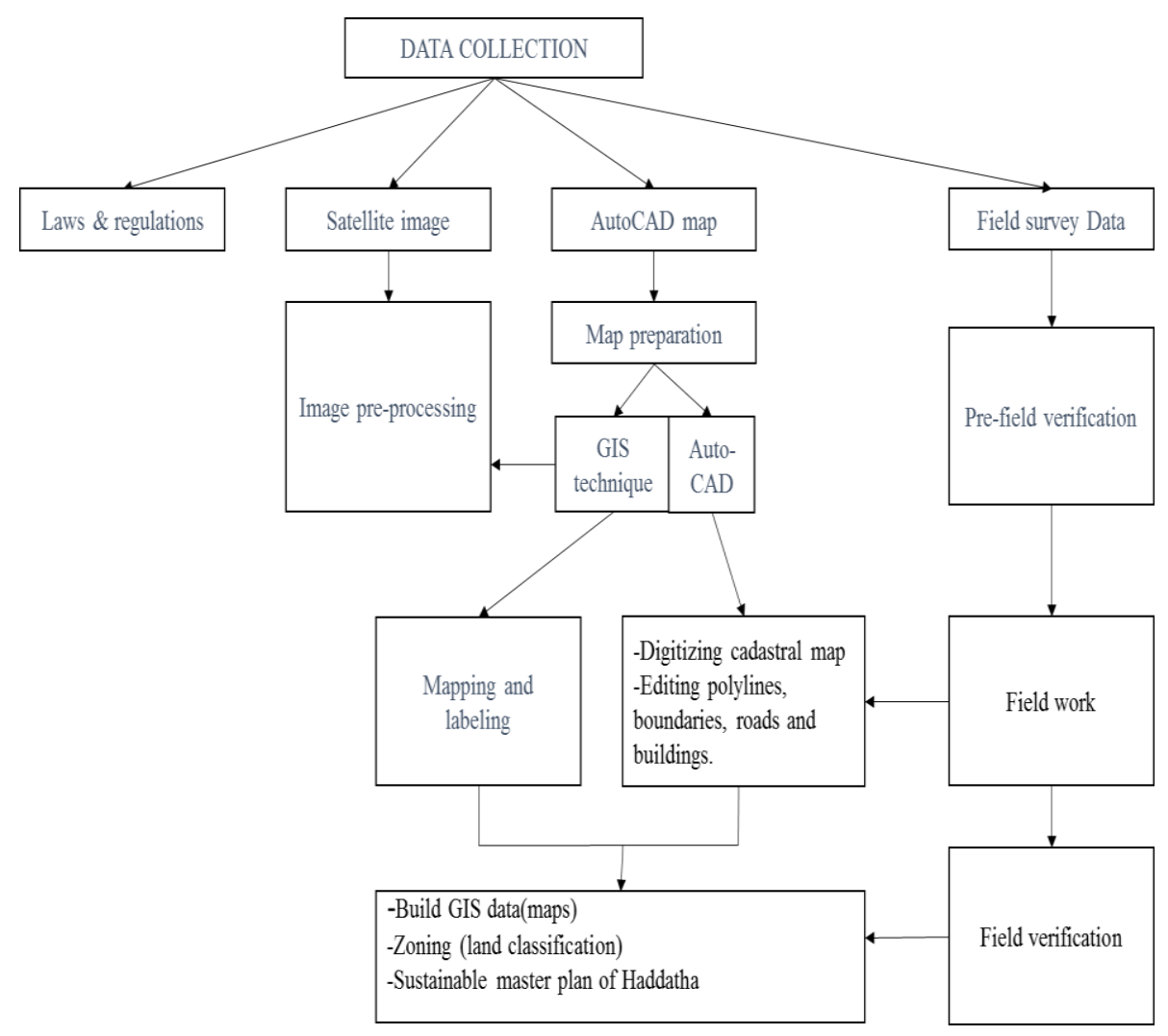

Fig. 4. Project workflow.

\section{Materials and methods}

In this part, we present the available sources that we used to collect the data (data collection), the software that we used (software processing), and the field visits.

The data collection consists of laws, maps, and satellite images.

-Maps: An AutoCAD map of the village and its land plots is prepared by scanning the maps made in 1960 by the Lebanese government and digitizing them. 
The digitized map and data gathered from the satellite images, using GIS software, were put together and then a geo-referencing process was done to provide a map that was used as the reference map for our project work.

-Satellite image: the satellite image used was obtained in 2018; it has a high resolution of $50 \mathrm{~cm}$ and an accuracy of 10-12m.

- Laws: we collected the land classification laws from the directorate general of the civil organization. Thus we, know and understand how this directorate analyzes and zones the villages.

- Map preparation: after collecting, incorporating, and cleaning the Cadastral maps of Haddatha, and then converting them from AutoCAD File to Arc Map, we lined everything up to modify features, export the selected features of the layers to a new shape file in ArcMap using the Export Data feature.

\section{Satellite Images and GIS Technique}

Urban planning and management is a complex task that cannot be completed without using a robust analytical tool such as GIS. GIS is used as an analytical and modeling tool in urban planning. GIS is important in monitoring the area or conducting a feasibility study for a site to develop a new urban plan or in the areas where design variables or alternative plans are required.

To obtain a more accurate result, a satellite image of the town must be used to manage and monitor the areas and green areas, especially to improve urban environments.

Satellite image data provides a detailed analysis of creating or updating GIS maps and discovering major changes in urban land cover and land use, enabling frequent overlapping and different time sequences to categorize the safe and environmentally sustainable areas of the proposed development region(s). The use of the satellite image medium or high resolution can support the monitoring of cities and lands, the monitoring of changes that require high details, and support decision-making for sustainable urban development in dense urban environments.

Accordingly, the GIS Data was built by preparing Cad files, editing polylines and boundaries of the land plots and roads, that are needed to make the maps easier to work with.

Now we have two excel sheets, one containing information about the land plots(number, area, zones, and some specifications) and the other containing information about subscriptions of generators (name of subscriber, the street, land plot number, and some specifications).

The excel files that contain the information's about the village, were cleaned, arranged, and handled. Then, these excel sheets were converted into GIS.

The satellite image was transformed from WGS84 UTM36N projection to stereo projection, and after geo-referencing the image by several limits, the satellite image is ready to be used.

GIS software used in our project to analyze the existing situation in Haddatha used to analyze the urban growth and its direction of expansion and to find suitable sites for further urban development.

Haddatha has about 2299 land plots, each having specific characteristics. Some land plots have 1 owner, while others may have many owners with different percentages, and land plots are planned in different zones according to different laws. 


\section{Field visits}

The field visit was conducted; 35 points collected using GPS (Geomax zenith pro) in order to complete the task. These points were used also for rectifying AutoCAD data and to georeference the satellite imagery.

Finally, the field visit was executed to take topological and other information that was neededfor the creation of the master plan.

\section{Results}

\subsection{Explanatory maps}

1 - A real state map that shows the land plots and Haddatha's boundaries (Figure 5).

Haddatha has2298 land plots and each land plot has specific characteristics.

2 - Land plot size map: land plot sizes vary in Haddatha village, starting from an area less than $500 \mathrm{~m}^{2}$ and up to some land plots with an area greater than $586,000 \mathrm{~m}^{2}$ (Figure 6).

3 - Land plot specification map: this map shows the developed and non-developed land plots (Figure 7).

Developed land plots: 535 land plots.

Non-developed land plots: 1764 land plots.

4 - The road network map shows the types of roads inside Haddatha that are needed in the zoning process (primary roads, secondary roads, and agricultural roads) (Figure 8).

5 - The residential area map shows the number of buildings per land plot (Figure 9). Using GIS software we can know the number of buildings per land plot (for example, when using GIS we can click on land plot number 13 and see that there are no buildings; on land plot 2187, there are two buildings, and land plot 2142 has only one building).

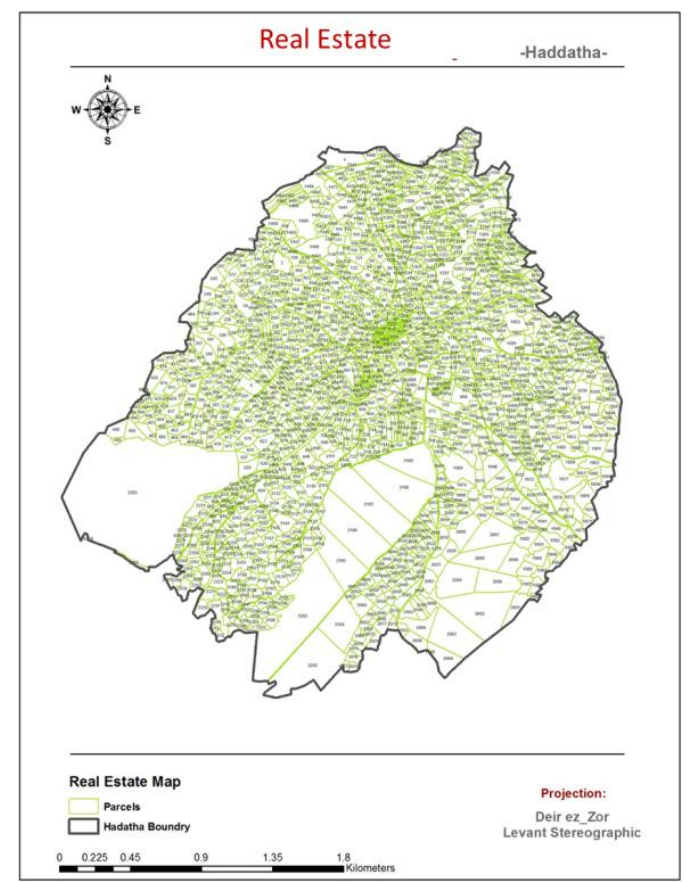

Fig. 5. Haddatha Real estate map. 


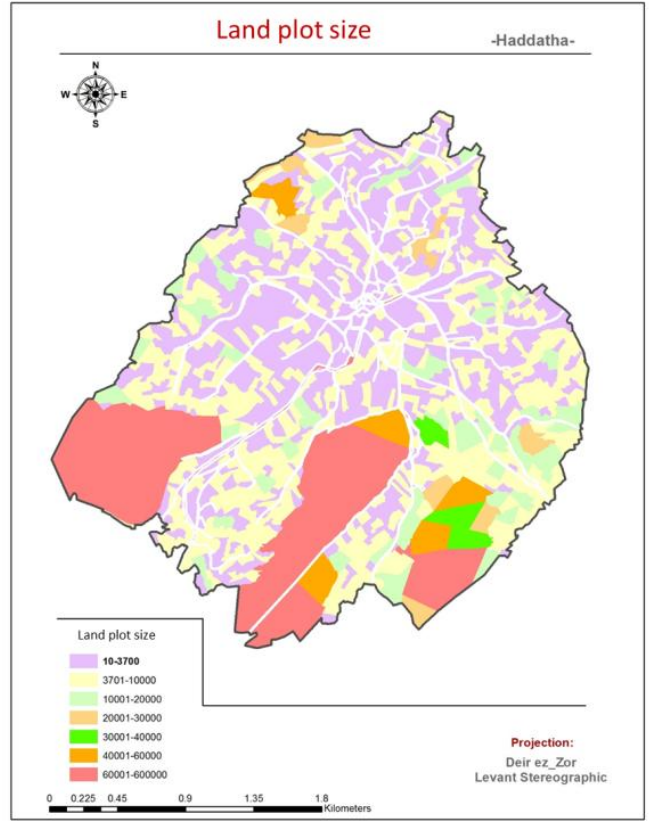

Fig. 6. Land plot size $\mathrm{m}^{2}$.

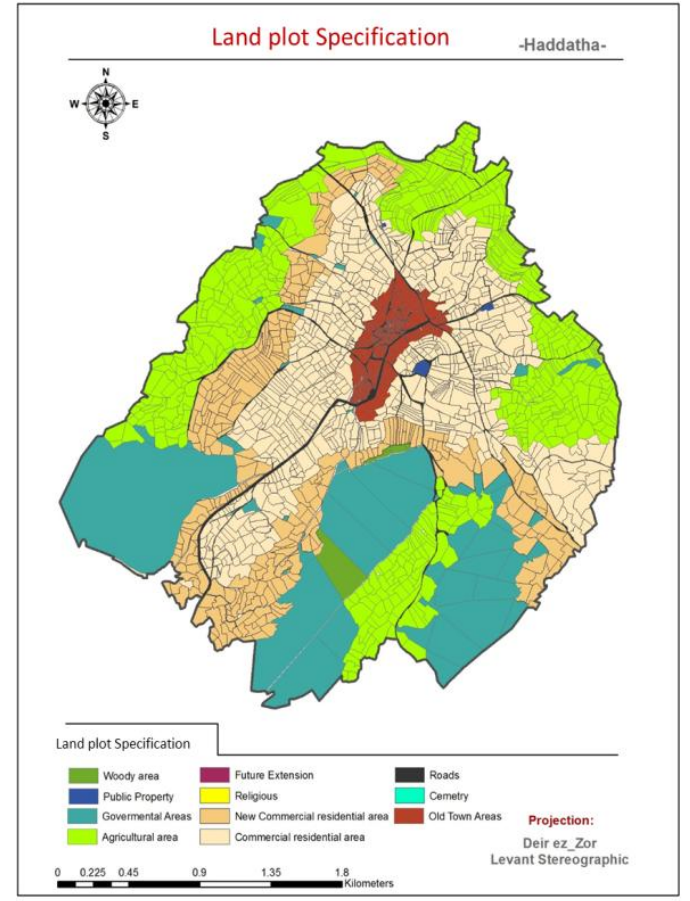

Fig. 7. Land Plot Specification. 


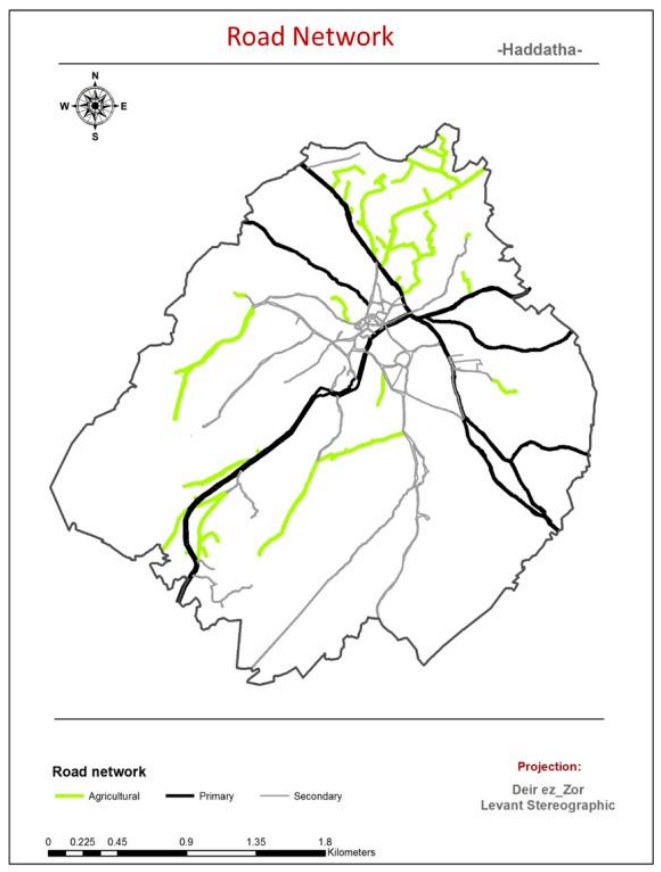

Fig. 8. Road Network Map.

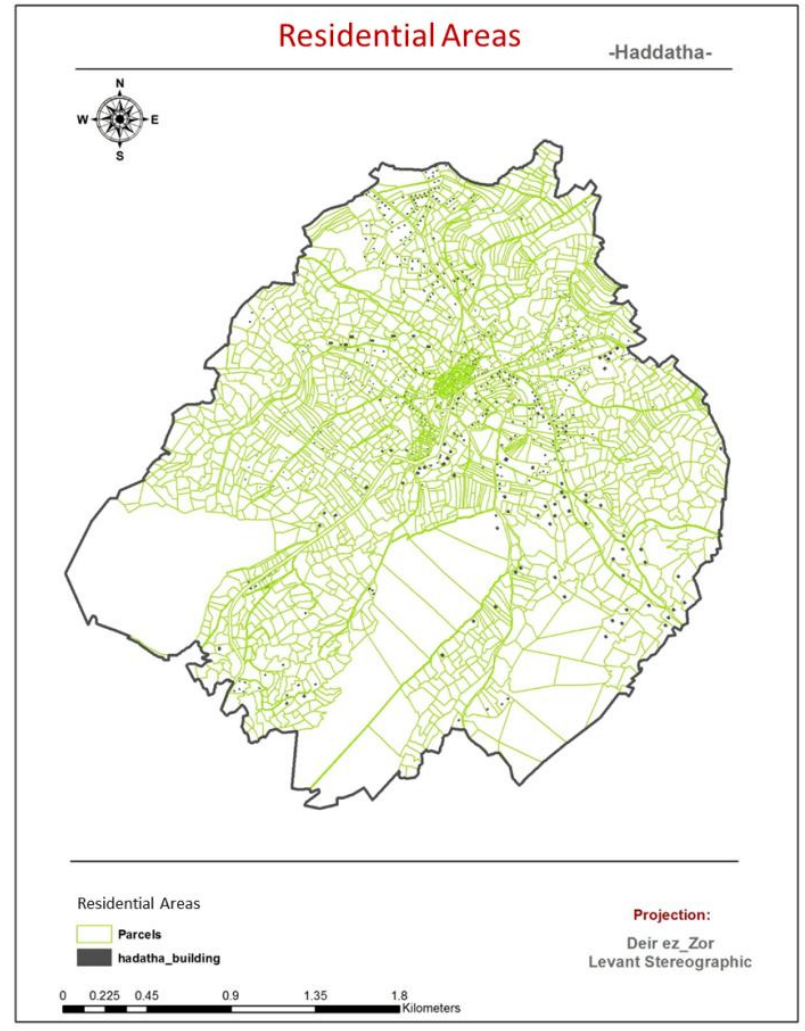

Fig. 9. Residential Areas map. 


\subsection{Master plan}

According to the norms that are being used in the General Directorate of Urban Planning in the zoning process classify, a high-residential area in the center of the village should have the highest investment. On the main roadside, the classification of the commercial and residential areas with a high-investmentcan be accepted. In forested areas and on the edge of the village, it is acceptable to classify agricultural areas (low investment).

Land-use classifications must be determined by adherence to the arrangements (front alignment, common parts, interfaces,) and functions (traffic, parking, access to facilities, commerce, etc.), the design of public places (street, patio, pedestrian turnover), the importance of trees and natural sites and distinctive views (over the mountains).According to the regulations of the General Directorate of Urban Planning, the zones in Haddatha were specified as we have shown in Table1:

Table 1. Land merge, subdivision, and investment regulations of Haddatha

\begin{tabular}{|c|c|c|c|c|c|c|c|c|c|c|c|c|c|c|}
\hline \multicolumn{15}{|c|}{ Land merge, subdivision, and investment regulations of Haddatha } \\
\hline & \multirow[t]{2}{*}{ Zone } & \multicolumn{3}{|c|}{ subdivision } & \multicolumn{3}{|c|}{$\begin{array}{c}\text { Existing } \\
\text { region buildable }\end{array}$} & \multicolumn{3}{|c|}{ Retreat } & \multirow{2}{*}{$\begin{array}{l}\text { Max } \\
\text { surfac } \\
\text { e } \\
\text { invest } \\
\text { ment } \\
\text { rate ( } \\
\%)\end{array}$} & \multirow{2}{*}{$\begin{array}{l}\text { Max. } \\
\text { publi } \\
\mathrm{c} \\
\text { inves } \\
\text { tent } \\
\quad \mathrm{f} \\
\text { actor }\end{array}$} & \multirow{2}{*}{$\begin{array}{l}\text { Flo } \\
\text { ors } \\
\text { num } \\
\text { ber }\end{array}$} & \multirow{2}{*}{$\begin{array}{l}\text { Ma } \\
\text { x. } \\
\text { hei } \\
\text { ght } \\
\text { (L. } \\
\text { m) }\end{array}$} \\
\hline & & $\begin{array}{l}\text { M } \\
\text { ax. } \\
\text { Ar } \\
\text { ea } \\
\text { (m } \\
\left.{ }^{2}\right) .\end{array}$ & $\begin{array}{l}\text { Min. } \\
\text { Inter } \\
\text { face } \\
\text { (L.m } \\
\text { ) }\end{array}$ & $\begin{array}{l}\text { Mi } \\
\text { n. } \\
\text { De } \\
\text { pth } \\
\text { (L. } \\
\text { m) }\end{array}$ & $\begin{array}{r}\text { Max } \\
\text { Area } \\
\text { after } \\
p \\
\text { lanni } \\
\text { ng. }\end{array}$ & $\begin{array}{l}\text { Min. } \\
\text { inter } \\
\text { face } \\
\text { (L.m } \\
\text { ) }\end{array}$ & $\begin{array}{l}\text { Mi } \\
\text { n. } \\
\text { de } \\
\text { pth } \\
\text { (L. } \\
\text { m) }\end{array}$ & $\begin{array}{l}\text { Und } \\
\text { o } \\
\text { plan } \\
\text { ning }\end{array}$ & $\begin{array}{l}\text { Sid } \\
\text { es } \\
\text { retr } \\
\text { act } \\
\text { (L. } \\
\text { m) }\end{array}$ & $\begin{array}{l}\text { Back } \\
\text { retract } \\
\text { (L.m) }\end{array}$ & & & & \\
\hline A & $\begin{array}{c}\text { Town } \\
\text { center } \\
\text { residen } \\
\text { ce }\end{array}$ & $\begin{array}{c}50 \\
0\end{array}$ & 5 & 15 & 250 & 2 & 2 & 3 & 2 & 2 & 60 & 1.2 & 2 & 9 \\
\hline B & $\begin{array}{c}\text { Reside } \\
\text { ntial \& } \\
\text { comme } \\
\text { rcial } \\
\text { Area }\end{array}$ & $\begin{array}{c}80 \\
0\end{array}$ & 0 & 20 & 500 & 5 & 5 & 3 & 3 & 3 & 30 & 0.9 & 3 & 12 \\
\hline $\begin{array}{l}\mathrm{B} \\
1\end{array}$ & $\begin{array}{c}\text { Reside } \\
\text { ntial \& } \\
\text { comme } \\
\text { rcial } \\
\text { Area }\end{array}$ & $\begin{array}{c}80 \\
0\end{array}$ & 0 & 20 & 500 & 5 & 5 & 3 & 3 & 3 & 30 & 0.9 & 3 & 10 \\
\hline $\mathbf{D}$ & $\begin{array}{c}\text { Moder } \\
n \\
\text { residen } \\
\text { tial and } \\
\text { comme } \\
\text { rcial } \\
\text { Area }\end{array}$ & $\begin{array}{l}10 \\
00\end{array}$ & 2 & 22 & 600 & 6 & 6 & 3 & 3 & 3 & 40 & 1.2 & 3 & 14 \\
\hline $\mathbf{F}$ & $\begin{array}{c}\text { Future } \\
\text { extensi } \\
\text { on }\end{array}$ & $\begin{array}{l}20 \\
00\end{array}$ & 5 & 35 & 1000 & 2 & 2 & 4.5 & 4.5 & 4.5 & 15 & 0.3 & 2 & 1.5 \\
\hline $\begin{array}{l}\mathbf{I} \\
\mathbf{N}\end{array}$ & $\begin{array}{c}\text { Public } \\
\text { institut } \\
\text { ions }\end{array}$ & $\begin{array}{l}20 \\
00\end{array}$ & 5 & 35 & 1000 & 2 & 2 & 3 & 4 & 4 & 30 & 0.9 & 3 & 12 \\
\hline
\end{tabular}




\begin{tabular}{|c|c|c|c|c|c|c|c|c|c|c|c|c|c|c|}
\hline & Area & & & & & & & & & & & & & \\
\hline $\begin{array}{l}\text { A } \\
\text { G }\end{array}$ & $\begin{array}{c}\text { Agricul } \\
\text { tural } \\
\text { Area } \\
\end{array}$ & $\begin{array}{l}50 \\
00\end{array}$ & 0 & 50 & 2500 & 5 & 5 & 5 & 5 & 5 & 5 & 0.05 & 1 & 4.5 \\
\hline G & $\begin{array}{c}\text { Forest } \\
\text { Area or } \\
\text { Affores } \\
\text { tation }\end{array}$ & $\begin{array}{l}60 \\
00\end{array}$ & 5 & 55 & 3000 & 0 & 0 & 6 & 6 & 6 & 5 & 0.05 & 1 & 4.5 \\
\hline $\mathbf{R}$ & $\begin{array}{c}\text { Endow } \\
\text { ment } \\
\text { Area } \\
\end{array}$ & \multicolumn{13}{|c|}{ Subject to special conditions } \\
\hline $\mathbf{C}$ & $\begin{array}{c}\text { Comm } \\
\text { only }\end{array}$ & $\begin{array}{c}60 \\
0\end{array}$ & 5 & 15 & 600 & 5 & 5 & 4 & 3 & 3 & 20 & 0.4 & 2 & 7.5 \\
\hline & Area & \multicolumn{13}{|c|}{ Subject to special conditions } \\
\hline $\mathbf{M}$ & $\begin{array}{c}\text { Graves } \\
\text { Area }\end{array}$ & \multicolumn{13}{|c|}{ Building is prohibited } \\
\hline
\end{tabular}

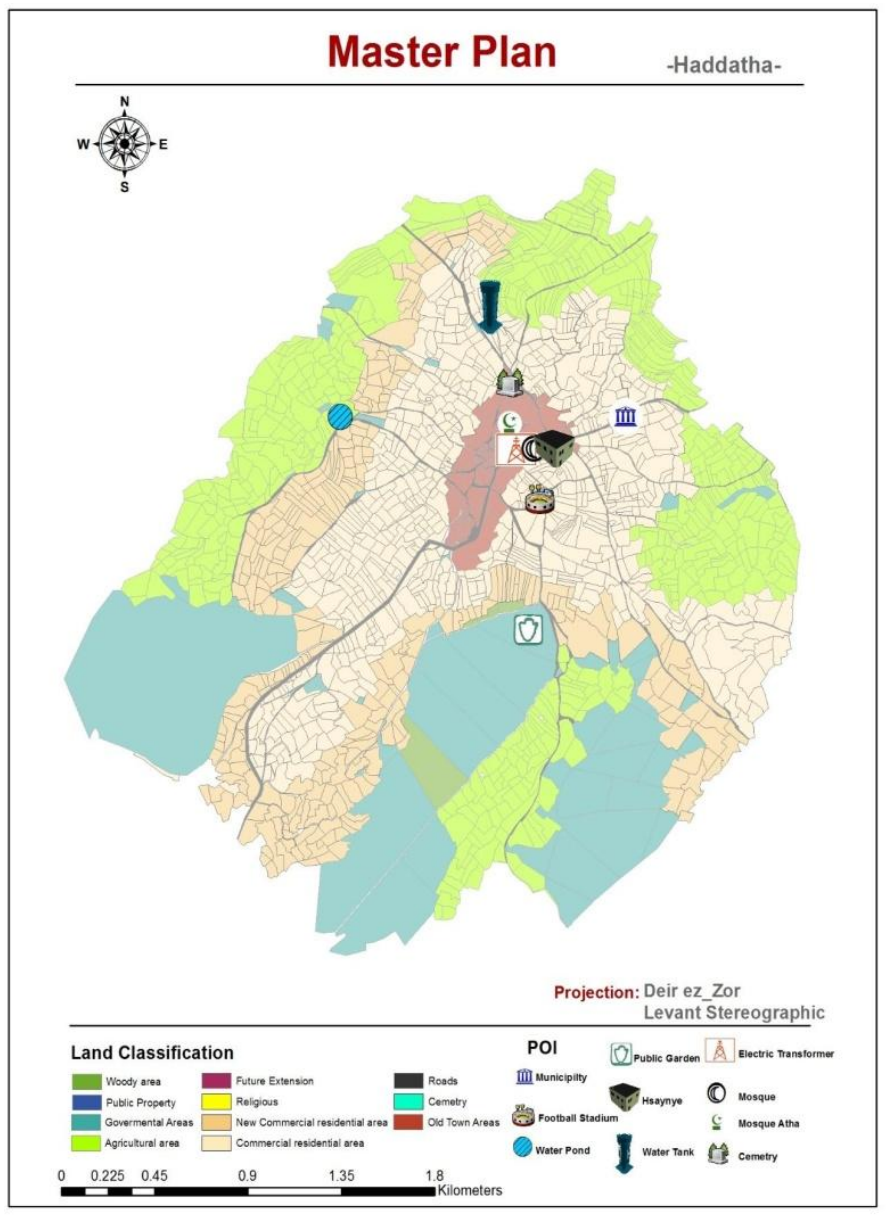

Fig. 9. Master Plan Map.

A master plan was designed for Haddatha village. This master plan shows: 
-The agricultural zone: 592 land plots.

-Commonly area: 61 land plots, area $=1,898,621 \mathrm{~m}^{2}$.

- The graves area: 3 land plots, area $=10174 \mathrm{~m}^{2}$.

- The residence area in the south of the centre: 376 land plots, area $=242,637 \mathrm{~m}^{2}$.

- The residential and commercial area: 924 land plots, area $=2,600,154 \mathrm{~m}^{2}$.

- The extension of the residential and commercial areas: 3331 and plots, area $=1,261,435$ $\mathrm{m}^{2}$.

- The Endowment Area: 53 land plots, area $=106,303 \mathrm{~m}^{2}$.

- The public institutions area: 4 land plots, area $=9,192 \mathrm{~m}^{2}$.

-Thea rea or afforestation: 7 land plots, area $=72,625 \mathrm{~m}^{2}$.

\section{Recommendations}

\section{Sustainable master plan:}

To apply a sustainable master plan to compile with the SDGs, we:

1 - Must achieve a disease-free social well-being - physically and mentally - with highquality healthcare systems that cover and protect everyone. Comprehensive health care must be provided including prevention and treatment of high blood pressure, diabetes, cancer, and other diseases, so that healthy population can achieve and reduce health care costs in the next 15 years (Goal\#3).

2- Haddatha residents suffer from frequent water shortages, and their water is not safe to drink. The water infrastructure must be improved and the supply of secure water management from the source to homes must be strengthened to ensure that Haddatha people have access to safe and sustainable drinking water supplies in the future. (Goal\#6)

3- Haddatha should start to abandon oil as the main fuel for energy and rely more on renewable energy sources from such resources as the sun, wind, and water.

4- Haddatha receives electricity within only 14 hours of 24 hours, so we notedinthe comments to the information that 635 land plots in this village depend on generators, which require a large consumption of oil, and the rate of air pollution increases significantly. By moving away from diesel oil as the main fuel for power production more sustainable forms, citizens could access more affordable power while also improving the environment (Goal\#7).

5- Should achieve goal\#12(responsible consumption and resources), goal\#13(climate action) and goal\#15(land and plants), because climate change is identified as a cross-cutting issue that needs to be addressed to ensure the successful implementation of all 17 Sustainable Development Goals. Due to climate change, Lebanon will be vulnerable to disasters, such as winter floods and hot summer days, which are increasing. But taking action to combat climate change now will allow our children to live in Lebanon that we know today. There are several solutions to reduce climate change:

a- $\quad$ The irrigation water required from safe natural water resources must be provided.

Since the economic movement in Haddatha consists of the agricultural, commercial, and industrial movement, there is a need to teach the agricultural techniques that can withstand the effects of climate and diversify income sources to help maintain stable livelihoods and contribute to economic growth and transform it into a green economy that greatly helps reduce the negative impact on the environment. Therefore, we should encourage the known crops of tobacco and olives that can increase financial revenues, improve health and welfare, and eliminate market failures.

b- Haddatha has some ancient springs and pond; measures must be taken to access freshwater and to activate drip irrigation technology and restoration of the existing pond to provide for collecting and carrying rainwater. 
c- Recycling and waste management must be introduced to eliminate toxic and contaminated waste. There is a method called home biogas, which is a biogas digester that treats organic waste locally and sustainably. It produces biogas for rich fertilizer for the garden.

d- Awareness of the benefits of sustainable consumption and production patterns must be achieved by adopting zero-carbon development to reduce emissions that would encourage flexible climate development. To adopt developing zero-carbon, it is necessary touse renewable energy, such as solar, water, or wind energy, and reduce the use of oil. Relying on zero-carbon development contributes to creating a cleaner and greener future. The use of low-carbon cement in building construction and the construction of green buildings helps to reduce energy and water consumption.

e- As Haddatha is rich in trees and has reserved trees, we can reduce the greenhouse emissions by protecting these existing trees and also promoting afforestation in public and private places in the village including public garden afforestation and the common areas to promote sustainable livelihoods, because deforestation and forest degradation help increase emissions.

f- We must monitor for the harvesting of wood and agriculture to protect, restore and enhance terrestrial ecosystems, support food, and water security, mitigate and adapt to climate change, and peace and security for and Lebanon and especially for Haddatha village.

g- Haddatha hasan old football stadium and has a public garden, but unfortunately this garden hasn't received any sufficient attention from the decision-makers, so they should be reconstructed to attain sustainable development.

Promote green buildings principle:

Keeping green and staying on the right side of things with the environment is easy. We should construct buildings or retrofit existing buildings; that perfectly meshes with the environment by using sustainable building materials. Energy and water efficiency have become simple these days by minimizing the use of non-renewable energy. There is a lot of solutions, for example, we can:

- Use wood that is considered a material that is sustainably harvested, which comes from well-managed forests.

- Use bamboo that is used mainly for flooring, as it is a grass and not wood and it is a sustainable material that renews quickly, or use of cork or cotton.

- Choose paints that have low VOC.

- Utilize floor coverings made of natural materials like wood for floors and wool for carpeting, rather than vinyl or man-made carpeting.

- Pursuit of Indoor Air Quality (IAQ) by eliminating and minimizing materials causing toxins and allergens to the air.

- Use solar energy, orient the site buildings so that thefaçade faces the sun.

- Make the outside lights timer to turn the light on only when needed.

- Collect rainwater in cisterns and use it for gardening.

- Avoid planting water-hungry landscaping.

\section{$3 d s$ max:}

Using the $3 \mathrm{ds}$ max, a $3 \mathrm{~d}$ model of the sustainable master plan was created to show the future image of Haddatha if we apply the SDGs solutions that were talked about (the renovated garden, football stadium, pond, a forestation) as we see in the figures below. 


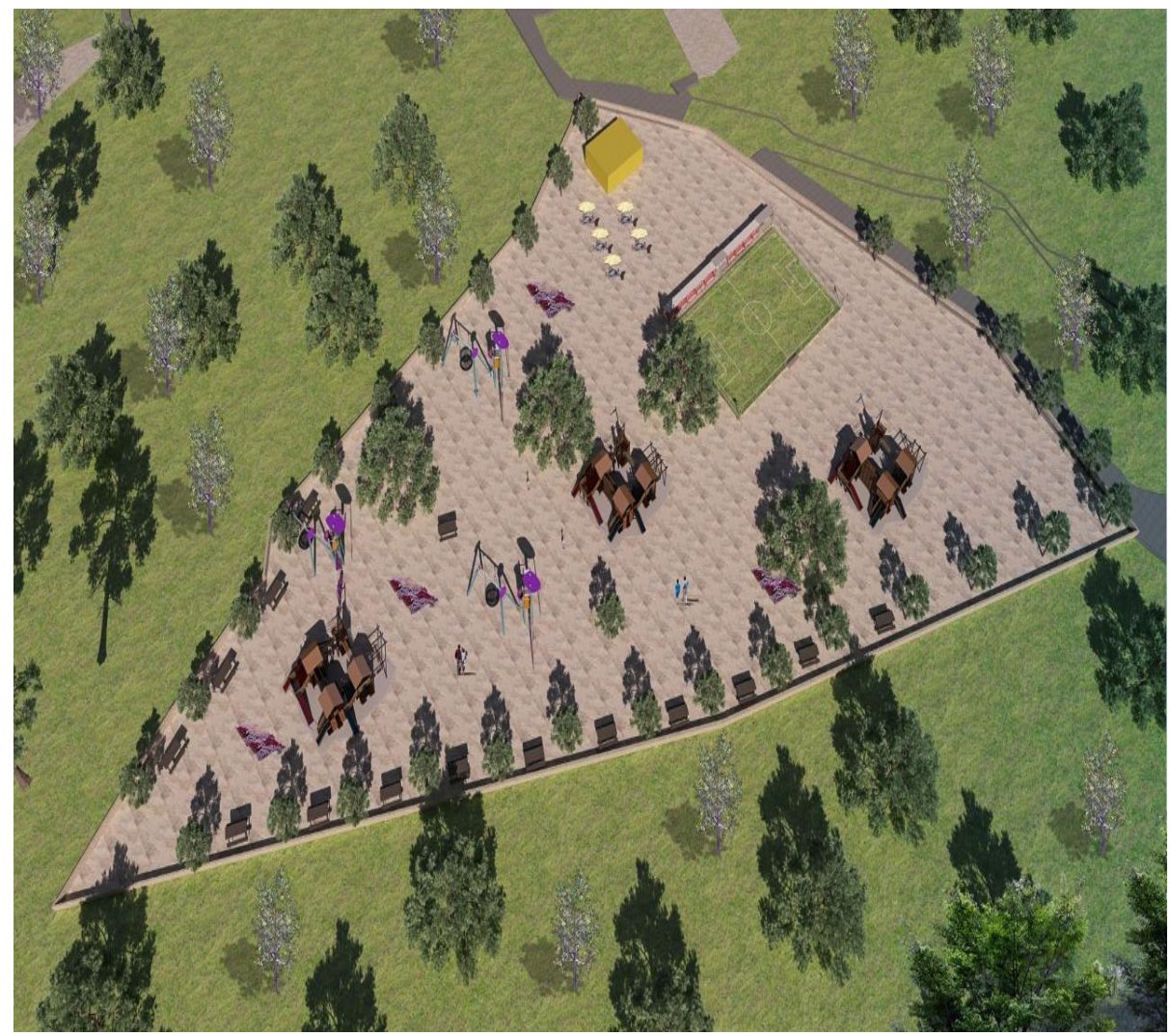

Fig. 11. Renovated garden and football stadium. 


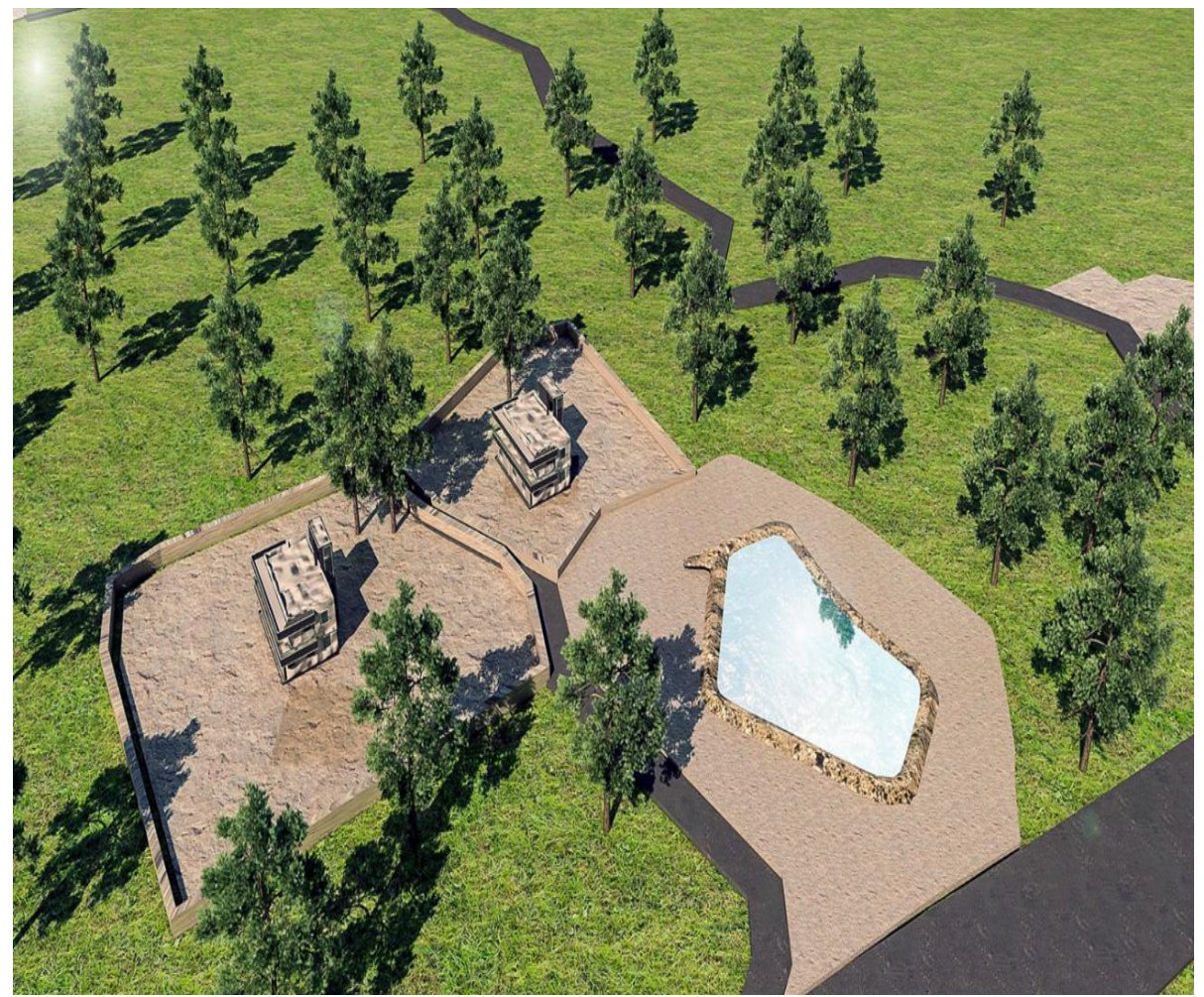

Fig. 10. Renovated pond(view 1).

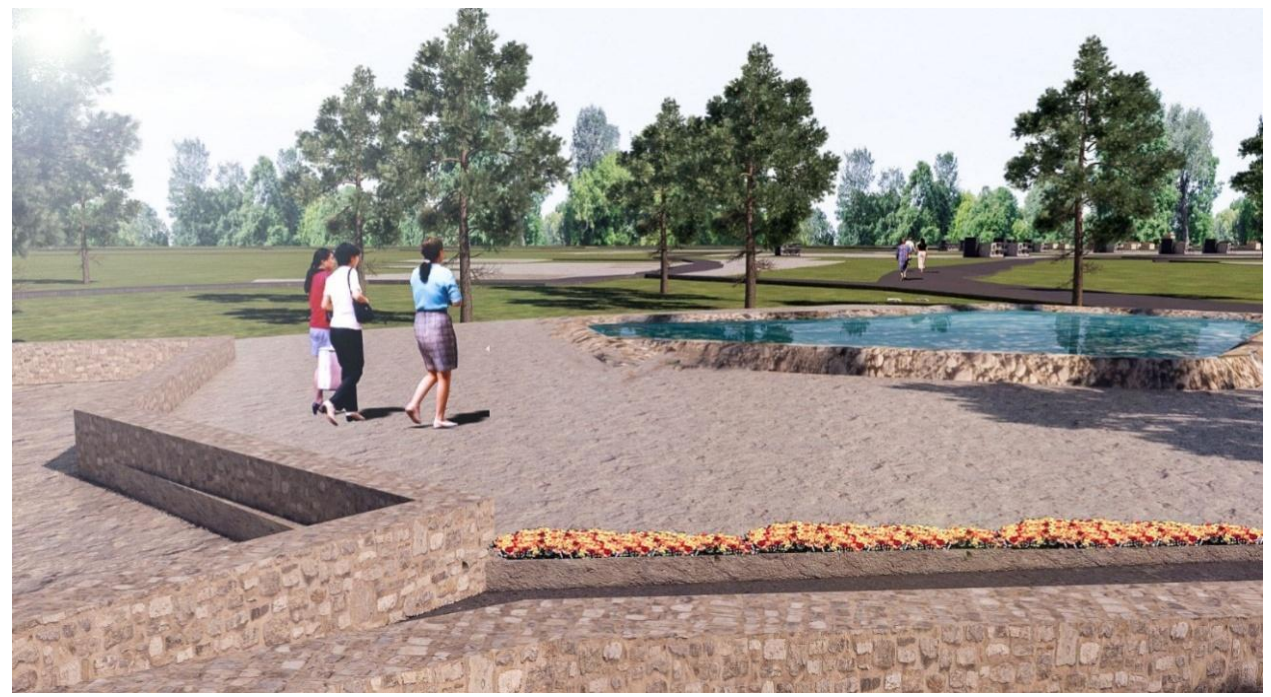

Fig. 10. Renovated pond (view 2).

\section{Conclusion}

The land of HADDATHA has a sustainable master plan, which facilitates and organizes the work of the municipality to carry out any new projects and to facilitate the use of lands and 
data; it also became possible to obtain digital data for the village. If we implement these solutions according to the SDGs to promote sustainable development in all contexts, we can start addressing challenges such as poverty, health, education, women's empowerment, growth, inequality, environmental protection, and we can provide ways to work for a better and a more equal future for the Lebanese themselves and the future generation.

\section{References}

1. Steen, R. S. Master plans \& zoning ordinances. Retrieved from Central Upper Peninsula Planning and Development Regional Commission(2015).

2. Sustainable Development Goals | UNDP in Lebanon. (n.d.). Retrieved from Sustainable Development Goals.

3. The Sustainable Development Goals 2017: Lebanon's report. Retrieved from 17 goals to transform our world in Lebanon (2017).

4. AL-Harithy. Lessons in post-war reconstruction: case studied from Lebanon in the aftermath of the 2006. London: Routledge (2010).

5. AL-Ebady, K.Masdar City in Abu Dhabi. Retrieved from Masdar City In Abu Dhabi (2019).

6. Farhat, I .Environmental considerations in the reconstruction of Beirut. Environment and Development(2001).

7. Bijker, Y. A. Inventory of remote sensing applications in forestry for sustainable management for sustainable management. Amsterdam: International Archives of Photogrammetry and Remote Sensing (2000).

8. Contributer, G. GIS in Urban Planning (2014).

9. Haddatha southern Lebanon. Retrieved from Ministry of interior and Municipalities Union of Municipalities of Bint Jbeil District(2012).

10. Haddatha south of Lebanon. Retrieved from the ministry of interior and municipalities, Union of Bint Jbeil District(2012).

11. Murphy, K. Sustainability: Science, Practice and Policy The social pillar of sustainable development: a literature review and framework for policy analysis(2012). 